\title{
Risk Management of DPLK Pension Funds of Sharia Financial Institutions (Evidence from a DPLK Pension Funds of Muamalat Sharia Financial Institutions)
}

\section{Septianingrum Dewi Purnamasari and Lina Nugraha Rani}

Department of Sharia Economics Faculty of Economics and Business Airlangga University

\section{Abstract}

The purpose of this research is to find out and analyze how the risk management of Sharia financial institution DPLK Pension Funds at the Muamalat Sharia Financial Institution DPLK Pension Fund (MSFIPF). This study uses qualitative methods with case study strategies. The object of this study was the Muamalat Sharia Financial Institution DPLK Pension Fund, an assessment was carried out using the Australian Standard / New Zealand Standard 4360: 1999 qualitative analysis method. The results of this

Corresponding Author: Septianingrum Dewi

Purnamasari

ningrumdewi01@gmail.com

Received: 10 February 2019 Accepted: 14 March 2019

Published: 28 March 2019

Publishing services provided by Knowledge E

(c) Septianingrum Dewi

Purnamasari and Lina Nugraha Rani. This article is distributed under the terms of the Creative Commons Attribution License, which permits unrestricted use and redistribution provided that the original author and source are credited.

Selection and Peer-review under the responsibility of the ICIEBP Conference Committee. study have found 5 types of risks identified namely strategic risk, operational risk, risk of assets and liabilities, reputation risk, and risk to participants. The results obtained from the risk assessment resulted in 17 types of risk descriptions, consisting of 4 types of risk descriptions with significant levels, 9 types of risk descriptions with moderate levels, and 4 types of risk descriptions with low levels. Based on the research it was found that a significant level is the level of risk description that must be considered highly because the opportunity is quite high and has a detrimental impact on the Muamalat Sharia DPLK Pension Fund. The level of risk description at the significant level of the Muamalat Sharia DPLK Pension Fund consists of 4 risk descriptions, among others, 3a. Investment returns are not in accordance with the benchmark, 3b. a mistake participants choose investment package (MSFIPF), 5a. fluctuating risk (participants), and $5 \mathrm{~b}$. a mistake in selecting investment packages (participants).

Keywords: Risk Management, Sharia DPLK Pension Fund, Muamalat Sharia DPLK Pension Fund

\section{Introduction}

\subsection{Background}

When an employee enters a non productive, then it can be said that employees will be entering retirement. According to the English-Indonesia, retirement is the time when 
State or position of the time of employees already can not work anymore because of the age factor, and health (Siagian, 1994:1).

The fulfillment of the rights of the employees as salary and benefits provided by the company will continue until the employee or the company resigned, were fired or retired. When employees have decided to quit or have entered retirement the company required to provide DPLK Pension Fund for each employee. therefore, the fulfillment guarantees future benefits need to be considered in a mature and necessary institution specifically designed to meet the future obligations (Siagian, 1994:1).

Based on data from the Central Bureau of statistics (BPS) in August 2016, the number of labor is included in the requirement of working alone, or being an employee of the company amounted to $70,233,078$ people but labor that have DPLK Pension Funds only of $6.24 \%$ i.e. of $4,189,527$ people. While it is estimated to be in the year 2025 , Indonesia will experience an increase in retirees have reached 40 million people. Thus the need for DPLK Pension Fund management institution is very important (www.ojk.go.id).

Considering the majority of society Indonesia are muslim and the adoption of Islam in the life of a muslim is very important, it must institute a DPLK Pension Fund is able to apply the principles of Sharia in any activity conducted (Soemitra, 2009:292). DPLK Pension Fund institution of Sharia has got the legality of the law with the promulgation of the fatwa Council of the National Assembly of the Sharia Ulama Indonesia (88/DSN$\mathrm{MUI} / \mathrm{XI} / 2013$ ) about the guidelines of the Organization of the program pensium based on sharia principles.

Based on non-bank Sharia finance industry (IKNB) statistics, January 2018 there is only one Sharia financial institution which provides DPLK Pension Fund DPLK Pension Fund i.e. Sharia financial institutions Sharia Muamalat Indonesia with total assets of Rp. 1.3 trillion (www.ojk.go.id)

Until now, Sharia Muamalat DPLK PENSION FUND or Muamalat Sharia DPLK Pension Fund has experienced growth in terms of Net Assets Value (NAV) in terms of membership, and as for net assets value (NAV) Muamalat in 2018 is Rp. 1,265,641,722,741 billion, an increase from the previous year Rp. 13,122,481,855 to the number of participants as much as 144,633 participants

With the rise of NAV and Sharia DPLK Pension Fund participants Offer Sharia Muamalat Indonesia, DPLK PENSION FUND will always be dealing with the various types of risk with different risk levels. The risk in the context of financial institutions (bank and non bank) is a potential occurrence, neither to be expected nor to be expected that negatively affect the finances of the company itself. Risk-the risk itself is inevitable but can be managed and controlled. 
According to the Circular letter of the financial services authority (No. 10/SEOJK 05/2016) about the application of risk management guidelines and reports the results of its own assessment of the application of risk management for financial services institutions the non Sharia banks, DPLK Pension Funds have risk possible illicit that will happen-that is, a risk strategy, operational risk, the risk of an asset and a liability, risk management, governance, risk and risk capital.

The risk of being one of a very important part in the management of a financial institution. Management policy goal is to identify, measure, and control the course of the business of financial institutions with a reasonable risk and tiers in directional, integrated, and sustainable, so that risk management serves as a filter or early warning against the activities of financial institutions.

\subsection{Summary of problem}

Based on the description of the background of the above then researchers formulate risk management problem of how DPLK Pension Funds of Sharia financial institutions in Sharia financial institution DPLK Pension Funds Muamalat?

\subsection{Research objectives}

Based on the formulation of the problem set out above, the purpose of this research is to know and analyze how DPLK Pension Fund risk management financial institutions Sharia financial institution DPLK Pension Funds on Sharia Muamalat.

\section{The Cornerstone of the Theory}

\subsection{Previous review}

According to the MUI fatwa DSN No. 88//DSN-MUI/XI/2013 Sharia retirement fund is a DPLK Pension Fund that held a retirement based on sharia principles. The Organization of the DPLK Pension Fund for Sharia program can be done by the employer or by submitting to the financial institutions that offer Sharia DPLK Pension Funds of the program services (Soemitra, 2009:292).

According to the MUI Fatwa DSN No. 88//DSN-MUI/XI/2013 type of retirement fund consists of two types namely DPLK Pension Fund Employer (DPPK) Financial Institutions and DPLK Pension Fund (DPLK). DPPK is a DPLK Pension Fund created by the person 
TABLE 1: Penelitian Terdahulu.

\begin{tabular}{|c|c|c|c|c|}
\hline No & Author & Title & Result & difference \\
\hline 1. & Blend (1998) & $\begin{array}{l}\text { Risk Management in } \\
\text { Insurance }\end{array}$ & $\begin{array}{l}\text { This research outlines the } \\
\text { aspects of risk } \\
\text { management as it applies } \\
\text { to the operation of } \\
\text { insurance and insurance } \\
\text { mediation. This research } \\
\text { focuses on the reputational } \\
\text { risk if the company can } \\
\text { manage their reputation } \\
\text { with good then customers } \\
\text { will have more confidence. } \\
\text { This study uses qualitative } \\
\text { methods }\end{array}$ & $\begin{array}{l}\text { In this study uses } \\
\text { financial institution } \\
\text { DPLK Pension Funds } \\
\text { object while using a } \\
\text { Blend of insurance } \\
\text { research research }\end{array}$ \\
\hline 2. & Akotey (2011) & $\begin{array}{l}\text { Risk Management in the } \\
\text { Ghanaian } \\
\text { Insurancelndustry. }\end{array}$ & $\begin{array}{l}\text { The results showed that } \\
\text { there are some differences } \\
\text { and similarities in the } \\
\text { practice of risk } \\
\text { management in life } \\
\text { insurance companies as } \\
\text { well as non-residents. This } \\
\text { study uses qualitative } \\
\text { methods comparative case } \\
\text { studies. }\end{array}$ & $\begin{array}{l}\text { In this study using the } \\
\text { object of DPLK } \\
\text { Pension Funds for } \\
\text { financial institutions } \\
\text { while research on the } \\
\text { insurance object using } \\
\text { Oscar }\end{array}$ \\
\hline 3. & $\begin{array}{l}\text { Rochmatul } \\
\text { (2015) }\end{array}$ & $\begin{array}{l}\text { Analisis Penerapan } \\
\text { Manajamen Risiko } \\
\text { Terhadap Ketidakpastian } \\
\text { (Uncertainty) yang } \\
\text { menghambat pencapaian } \\
\text { tujuan perusahaan (studi } \\
\text { kasus pada PT Taspen } \\
\text { (Persero)) (Analysis of the } \\
\text { Application of Risk } \\
\text { Management Against } \\
\text { Uncertainty which hampers } \\
\text { the achievement of } \\
\text { corporate objectives (case } \\
\text { study at PT Taspen } \\
\text { (Persero))) }\end{array}$ & $\begin{array}{l}\text { The results of this research } \\
\text { show that the application } \\
\text { of risk management in PT } \\
\text { Taspen (Persero) Surabaya } \\
\text { Branch Office yet because } \\
\text { it is still effectively, } \\
\text { implement process control } \\
\text { inherent in every area, } \\
\text { where each field has a } \\
\text { control remain in the } \\
\text { supervision of the Office of } \\
\text { the Centret }\end{array}$ & $\begin{array}{l}\text { This research uses the } \\
\text { object of Sharia } \\
\text { financial institution } \\
\text { DPLK Pension Funds, } \\
\text { while in this study } \\
\text { using conventional } \\
\text { DPLK Pension Funds } \\
\text { object }\end{array}$ \\
\hline
\end{tabular}

or agency that employs the employee as the founder, to hold the Retirement Benefits for sure (PPMP) or defined contribution Retirement Program (PPIP), whereas DPLK is a DPLK Pension Fund created by Bank or insurance company to hold the retirement Program Tuition is definitely good for individuals, employees as well as self-employed

There are two products of DPLK Sharia Muamalat, Muamalat Protected Pension Program using wakalah aqad bill management fee and Muamalat Protected Severance Program using aqad hibah bi Syarth and billing management fee wakalah.

According to the Financial Services Authority circular letter No. 10/SEOJK. 05-2016 on the implementation of the guidelines on risk management and self-assessment results reports on the application of risk management for financial services institutions the non Sharia bank, there are six types of risk on pensions Sharia among them, namely 
the risk strategy, operational risk, the risk of an asset and a liability, risk management, governance, risk and risk capital.

Processes or stages that are conducted in an attempt to confront and manage a risk depends on the basic concept that embraced. Following the concept of risk management according to Standards Australia/New Zealand Standard (4360:2004), which began the process of communication and consultion, establishing the context, risk assessment consisting of the identification, analysis, and evaluation, after conducted risk assessment then conducted the handling of risks, monitoring and review.

\section{Research Methods}

As for the reason for using a qualitative approach in this study is due to answer questions on the outline of the problem comprehensively and in depth about how risk management on Sharia financial institution DPLK Pension Funds on the Fund Sharia Muamalat Financial Institutions Pensions. The question "how" (how) this is more appropriately answered using qualitative approach, since in this study researchers do not have the opportunity to control the object of research. Researchers also want to obtain in-depth data to reveal the fact that occurs on the object of research, namely risk management is applied to the DPLK Pension Fund Institution Muamalat Sharia finance.

The unit of analysis in this research is the process of risk management in financial institution DPLK Pension Funds of Sharia Muamalat, a series of process is made up of:

1. Risk Identification

2. Risk Analysis

3. Risk Treatment

4. and other things that will be encountered in the field

The scope of the research includes:

1. The research is focused on risk management the management of DPLK Pension Funds of financial institutions Sharia Muamalat.

2. Scope only limited research on risk management of Sharia financial institution DPLK Pension Funds.

3. Objects in this research are the DPLK Pension Funds Sharia finance institutions Muamalat in Gd. Muamalat Tower 10th floor JL. Prof. Dr. Satrio No. 18. Kuningan, 
South Jakarta. The naming of such financial institutions as it is a financial institution DPLK Pension Funds

Types and sources of data in this study is the primary data that comes from Interviews conducted with the Chief investment, Relation Marketing, head of marketing, Acting Superintendent, and two clients. Secondary data is data obtained indirectly. Secondary data in research first, obtained from an explanation of risk management of Sharia financial institution DPLK Pension Funds that support chapter 1 and Chapter 2 in this study, and also the structure of organizations, websites, books, journals, newspapers, and document or report has ever done research activities relating to risk management of Sharia financial institution DPLK Pension Funds and relevant sources.

Data collection techniques used in this study is to document or collection record, interview, observation and observation, which is using the procedure of using primary data starting from getting started with how to take care of the mail permission to research formal academic by Faculty of Economics and business Airlangga University, the process of entering a location, i.e. by way of asking about Sharia DPLK Pension Funds at branch offices, and through social media, time on site research object starting from the conduct interviews to the informant with questions about DPLK Pension Fund risk management financial institutions Sharia Muamalat ranging from gathering together the funds, fund management, and disbursement of funds, after collecting primary data with interviews, researchers conducting a literature review and literature mengenani DPLK Pension Fund risk management of financial institutions.

Analytical techniques used in this research is the data analysis techniques, namely with the reduction of the data, the presentation of data, and conclusions.

\section{Results and Discussion}

\subsection{The concept of management of Sharia Muamalat DPLK Pension Fund}

Based on research, the Institute is Sharia Muamalat (DPLK) DPLK Pension Funds the first Sharia-compliant and being the only one in Indonesia. The most fundamental difference between Sharia Muamalat (DPLK) DPLK Pension Funds with conventional (DPLK) DPLK Pension Funds is managing DPLK Pension Fund products offered are not fully Sharia because they can allow that those funds would be invested into the sector that do not comply with its Sharia. 


\subsection{Gathering together the Sharia Muamalat DPLK Pension Fund participant funding}

In managing Sharia Muamalat (DPLK) DPLK Pension Funds, branch offices of Bank Muamalat Indonesia plays An active role in the process of registration of new participants individu corporations, gathering together the Fund participant, and the process of disbursement of participants.

In Sharia Muamalat (DPLK) DPLK Pension Funds market products special koporasi which became the focus of Sharia Muamalat (DPLK) DPLK Pension Funds, there are several strategies that is by way of plunging directly into each company of potentially doing a presentation and explain regarding Sharia Muamalat DPLK Pension Fund product benefits, in order to attract companies to enroll employees. In gathering together the Fund participant, the planned retirement of the product and the product proposed severance Muamalat Muamalat are not required to pay dues each month, but dues dibayarknan a minimum of Rp 50,000 per participant.

\subsection{Management of the fund participant DPLK Pension Fund Sharia Muamalat}

Management of the Fund participant DPLK Pension Fund Sharia Muamalat investment packages based on the selected participants in the initial registration. Participant funding is managed on the money market and the capital market through the invesatsi package is available, i.e., A package that consists of $100 \%$ deposit, package $B$ consists of deposits and Sukuk (80\%), and the $\mathrm{C}$ package consisting of deposits, mutual funds (80\%), and shares (50\%).

The selection of the investment packages based on the risk profile of the participants, so that the investment team was instrumental to determine the best position of the capital market, and explain about investment packages to participants.

In the Organization of the participant Fund, needed an agreement among participants with the Sharia Muamalat DPLK Pension Fund commonly called aqad, as for the Organization of the participant Fund aqad are wakalah aqad for bill management fee, for planned product Muamalat, Pension Fund using aqad hibah bi syarth and then billing management fee and Muamalat severance plan is planned are using wakalah aqad. 


\subsection{Disbursement participants DPLK Pension Fund Sharia Muamalat}

In the process of disbursement of funds, participants can also ask in branch offices throughout Indonesia, with Muamalat submit requirements needed. After participants withdraw dananyanya at Sharia Muamalat DPLK Pension Fund, party branch Muamalat will send the file to the Sharia Muamalat DPLK Pension Fund headquarters for in the process.

In the disbursement of Sharia Muamalat DPLK Pension Fund participants, requires time for 7 working days, while if participants withdraw funds via Muamalat branches then the time required during 14 days of work, and when in 365 days, participants who have entering the age of retirement has not filed the melting process then the Fund will enter into the Auction of State Treasure Hall.

\subsection{Risk identification DPLK Pension Fund Sharia Muamalat}

Based on the results of research on Sharia Muamalat DPLK Pension Fund, these institutions have a way of identifying risks is to analyze the event or events that give rise to the influence and effect of the risk adverse nature and view events in the past that could potentially show up again later in the day.

\subsection{The risk at this stage of gathering together the participants}

In the stage of gathering together the Fund participant, there are a number of constraints: 


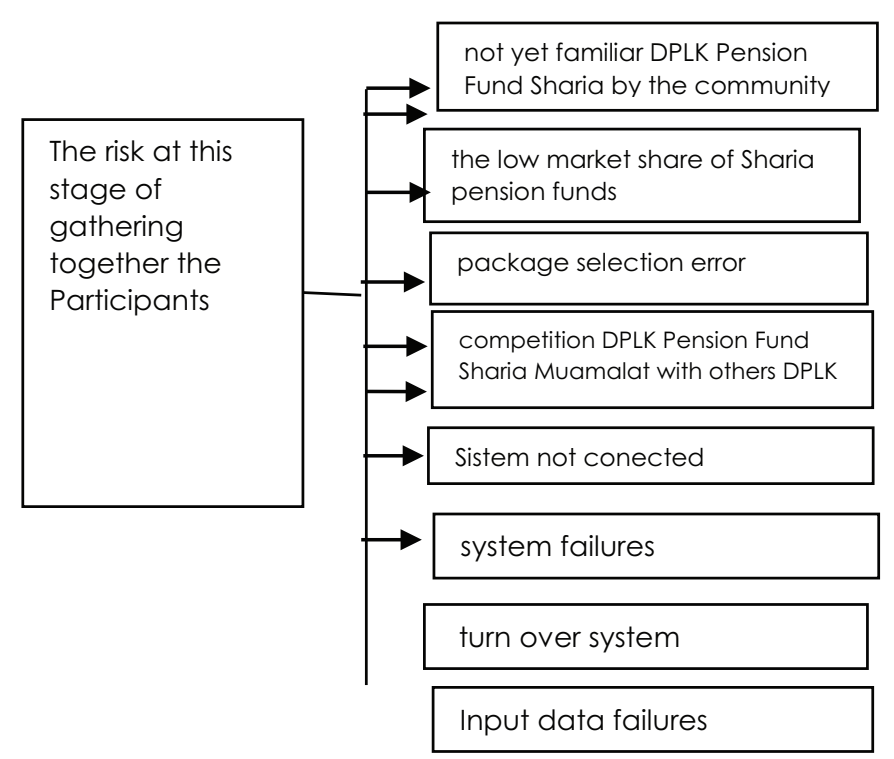

\subsection{Risk in the management of the fund participant}

The main constraint in terms of internal company management related, lies in the management of human resources is still affiliated with the Bank Muamalat which caused the employee to resign if there is then an important outposts in the organizational chart will be empty, other than This risk in the management of the Fund participants located at the risk of rinvestasi the result is not in accordance with the benchmarks. Further risk to the ups and downs of the stock market value

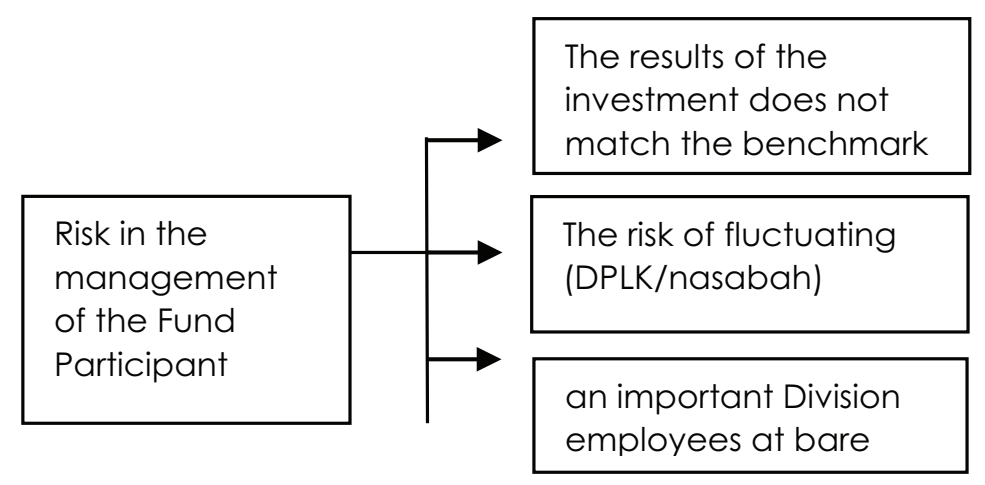

\subsection{Risk in the disbursement of participants}

At the stage of melting, there are also some constraints, namely terpengaruhnya parties shall issue participants reporting negative, due to a mismatch of the investment package to meda, and law enforcement authorities, in addition to the delay in the delivery of files by the branch to the Office of the Centre will also be a constraint. 


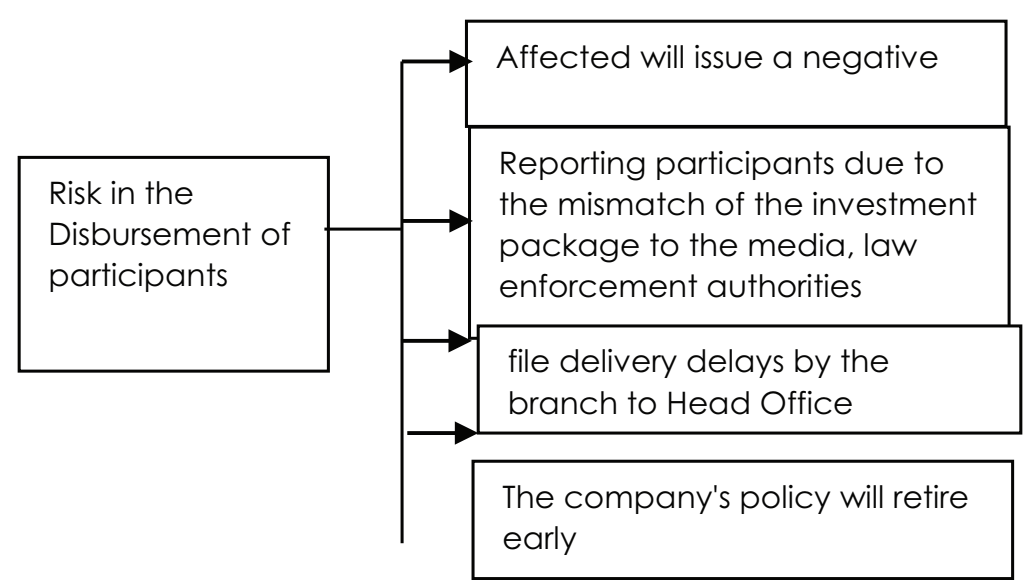

The table below is a list of the identification of risk and the granting of the code against the risk

\subsection{Risk analysis}

After the identification of the risk, the next step is the risk assessment conducted by a third informant for each type of risk identified. The following is an assessment of the risks that have been identified 5 :

\subsubsection{Strategy risk}

Risk strategy first is 1a. Yet the introduction of Sharia Muamalat DPLK Pension Fund by society. Based on research, the informant first (head of investment) provide an assessment of the probability of occurrence of risks of 1a. Yet the introduction of Sharia by DPLK Pension Fund product the public is likely to occur (4) and have an impact with the value 2 . The impact caused when the risk occurs according to the informants is a reasonable thing in Indonesia at umunya community there are still many who have not yet learned of the DPLK Pension Fund of Sharia financial institutions development given the still classified as new, so in the process of the introduction of Sharia DPLK Pension Fund Muamalat products, aided by party branch offices of Bank Muamalat.

The next risk is $1 \mathrm{~b}$. the low market share of DPLK Pension Fund. Based on the statement of the first informant (head of investments) that the probability of happening likely risk 1b low market share of Sharia is a small DPLK Pension Fund likely (2), and having an impact with a value of 2 . That is because in seizing market share DPLK Pension Fund Sharia Muamalat requires assistance from the branch offices of the Bank Mamalat, given in the marketing division has only 4 employees, so with limited human resources 
TABLE 2: The list of risks and Risk Code Granting.

\begin{tabular}{|c|c|c|c|c|c|c|}
\hline \multirow[t]{2}{*}{ No } & \multirow[t]{2}{*}{ Types of risk } & \multirow[t]{2}{*}{ code } & \multirow[t]{2}{*}{ Description of risk } & \multicolumn{2}{|c|}{ risk sources } & \multirow{2}{*}{$\begin{array}{l}\text { the type of management } \\
\text { of the DPLK Pension } \\
\text { Fund }\end{array}$} \\
\hline & & & & internal & External & \\
\hline \multirow[t]{3}{*}{1} & Risk Strategy & $1 \mathrm{a}$ & $\begin{array}{l}\text { not yet familiar DPLK } \\
\text { Pension Fund Sharia by } \\
\text { the community }\end{array}$ & $\sqrt{ }$ & & $\begin{array}{l}\text { The risk at this stage of } \\
\text { gathering together the } \\
\text { Participants }\end{array}$ \\
\hline & & $1 \mathrm{~b}$ & $\begin{array}{l}\text { the low market share of } \\
\text { Sharia DPLK Pension } \\
\text { Fund }\end{array}$ & $\sqrt{ }$ & & $\begin{array}{l}\text { The risk at this stage of } \\
\text { gathering together the } \\
\text { Participants }\end{array}$ \\
\hline & & 1c & package selection error & $\sqrt{ }$ & & $\begin{array}{l}\text { The risk at this stage of } \\
\text { gathering together the } \\
\text { Participants }\end{array}$ \\
\hline \multirow[t]{6}{*}{2} & $\begin{array}{l}\text { Operational } \\
\text { Risk }\end{array}$ & $2 a$ & Sistem not connected & $\sqrt{ }$ & & $\begin{array}{l}\text { The risk at this stage of } \\
\text { gathering together the } \\
\text { Participants }\end{array}$ \\
\hline & & $2 b$ & turn over system & $\sqrt{ }$ & & $\begin{array}{l}\text { The risk at this stage of } \\
\text { gathering together the } \\
\text { Participants }\end{array}$ \\
\hline & & $2 c$ & system failures & $\sqrt{ }$ & & $\begin{array}{l}\text { The risk at this stage of } \\
\text { gathering together the } \\
\text { Participants }\end{array}$ \\
\hline & & $2 d$ & Input data failures & $\sqrt{ }$ & & $\begin{array}{l}\text { The risk at this stage of } \\
\text { gathering together the } \\
\text { Participants }\end{array}$ \\
\hline & & $2 e$ & $\begin{array}{l}\text { file delivery delays by } \\
\text { the branch to Head } \\
\text { Office }\end{array}$ & $\sqrt{ }$ & & $\begin{array}{l}\text { Risk in the management } \\
\text { of the Fund Participant }\end{array}$ \\
\hline & & $2 f$ & $\begin{array}{l}\text { an important Division } \\
\text { employees at bare }\end{array}$ & $\sqrt{ }$ & & $\begin{array}{l}\text { Risk in the management } \\
\text { of the Fund Participant }\end{array}$ \\
\hline \multirow[t]{4}{*}{3} & $\begin{array}{l}\text { Asset and } \\
\text { Liability Risk }\end{array}$ & $3 a$ & $\begin{array}{l}\text { The results of the } \\
\text { investment does not } \\
\text { match the benchmark }\end{array}$ & $\sqrt{ }$ & & $\begin{array}{l}\text { Risk in the management } \\
\text { of the Fund Participant }\end{array}$ \\
\hline & & $3 b$ & $\begin{array}{l}\text { package selection error } \\
\text { (DPLK Pension Fund) }\end{array}$ & $\sqrt{ }$ & & $\begin{array}{l}\text { The risk at this stage of } \\
\text { gathering together the } \\
\text { Participants }\end{array}$ \\
\hline & & $3 c$ & $\begin{array}{l}\text { The risk of fluctuating } \\
\text { (DPLK Pension Fund) }\end{array}$ & & $\sqrt{ }$ & $\begin{array}{l}\text { Risk in the management } \\
\text { of the Fund Participant }\end{array}$ \\
\hline & & $3 d$ & $\begin{array}{l}\text { The company's policy } \\
\text { will retire early }\end{array}$ & & $\sqrt{ }$ & $\begin{array}{l}\text { Risk in the Disbursement } \\
\text { of participants }\end{array}$ \\
\hline \multirow[t]{2}{*}{4} & $\begin{array}{l}\text { Reputation } \\
\text { risk }\end{array}$ & $4 a$ & $\begin{array}{l}\text { Affected will issue a } \\
\text { negative }\end{array}$ & & $\sqrt{ }$ & $\begin{array}{l}\text { Risk in the Disbursement } \\
\text { of participants }\end{array}$ \\
\hline & & $4 b$ & $\begin{array}{l}\text { Reporting participants } \\
\text { due to the mismatch of } \\
\text { the investment package } \\
\text { to the media, law } \\
\text { enforcement authorities }\end{array}$ & $\sqrt{ }$ & & $\begin{array}{l}\text { Risk in the Disbursement } \\
\text { of participants }\end{array}$ \\
\hline \multirow[t]{2}{*}{5} & $\begin{array}{l}\text { the risk of } \\
\text { participants }\end{array}$ & $5 a$ & $\begin{array}{l}\text { The risk of fluctuating } \\
\text { (nasabah) }\end{array}$ & & $\sqrt{ }$ & $\begin{array}{l}\text { Risk in the management } \\
\text { of the Fund Participant }\end{array}$ \\
\hline & & $5 b$ & $\begin{array}{l}\text { package selection error } \\
\text { i (nasabah }\end{array}$ & & $\sqrt{ }$ & $\begin{array}{l}\text { The risk at this stage of } \\
\text { gathering together the } \\
\text { Participants } t\end{array}$ \\
\hline
\end{tabular}


owned, then it is likely to capture market share in the large number of increasingly limited.

Next is the risk of $1 \mathrm{c}$. Sharia Muamalat DPLK Pension Fund competition with others DPLK Pension Fund, which has linkages with the specific strategies that may affect a large number of gathering together the new participants. based on the statements of the second informant (relation marketing) such risk may occur (4), but the impact caused no significant (1). That is because the rivalry with Sharia DPLK Pension Fund others DPLK Pension Fund is a healthy competition, i.e. by way of presenting the primacy of individual DPLK Pension Fund without any elements of each, so that the risk is very reasonable indeed and it has been going on since the first Sharia Muamalat DPLK Pension Fund stand. The conclusion from all the statements of informants in a risk assessment table formed strategies as follows:

TABLE 3: Risk assessment risk strategy (Source: data process by writer).

$\begin{array}{ll}\text { Code } & \text { Description of risk } \\ \text { 1a } & \begin{array}{l}\text { not yet familiar DPLK } \\ \text { Pension Fund Sharia by the } \\ \text { community }\end{array} \\ \text { 1b } & \begin{array}{l}\text { The low market share of } \\ \text { Sharia DPLK Pension Fund }\end{array} \\ \text { 1c } & \begin{array}{l}\text { Competition DPLK } \\ \text { PENSION FUND Sharia } \\ \text { Muamalat with others DPLK } \\ \text { Pension Fund }\end{array}\end{array}$

\begin{tabular}{c} 
Opportunities \\
4 \\
\hline 2 \\
\hline 4 \\
\hline
\end{tabular}
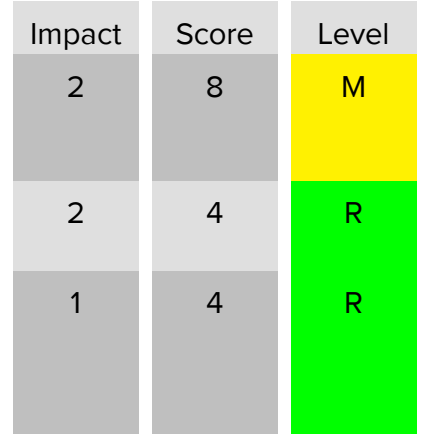

TABLE 4: Matrix Risk assessment Risk Strategy (Source: data process by writer).

OPPORTUNITIES
5. almost certainly
4. likely
3. moderate
2. Unlikely
1. Rare

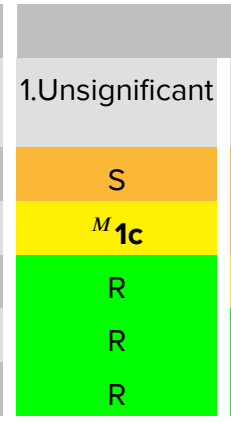

\begin{tabular}{c} 
2.Minor \\
\hline $\mathrm{S}$ \\
$S_{\text {la }}$ \\
\hline $\mathrm{M}$ \\
${ }^{R}$ 1b \\
$\mathrm{R}$ \\
\hline
\end{tabular}

\section{IMPACT}

3. moderate
T
S
S
M
M

4.Major
T
$\mathrm{T}$
$\mathrm{T}$
$\mathrm{S}$
$\mathrm{S}$

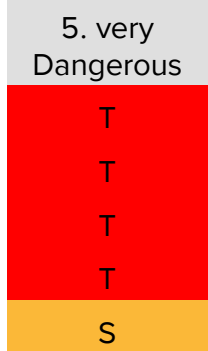

\subsubsection{Operational risk}

The first operational risk is system terkoneksinya yet 2a DPLK Pension Fund Sharia Muamalat system founder. Based on the statement of the first informant (head of investment) such risk may occur (4), in addition to the impact caused when the risk occurs is a minor or has a value of 2 , that is because the system used by Branch Office 
has existed since long ago, but the current bank Muamalat has been migrated to use the new system. but will the new system still needs to be done.

The next risk is $2 \mathrm{~b}$. systems that turn over. Based on informant first (head of investment) the possibility of the occurrence of the risk that is unlikely or level 2 , but to impact major (4). That is because those risks will be greatly give impact on the survival of Sharia Muamalat DPLK Pension Fund.

The next risk is $2 \mathrm{c}$. the failure of the system. Based on the statement of a third informant (head of marketing) the possibility of the occurrence of the risk has a value of 3 or medium, but the impact caused when the risks occur is not significant, because the failure login system is a reasonable thing, and until recently the problem can still be handled well.

The next risk is the risk of $2 \mathrm{~d}$. error when penginputan data. Based on the statements of the second informant (relation marketing), the risk might just happen or has a level 4 , and the opportunities that will be brought about when the risk occurs is a minor or has a level 2.

The next risk is $2 e$ file delivery delays by the branch to head office. Based on the statement of a third informant (head of marketing), the risk that may occur (4) and the impact when the risk occurs is minor (2). That is because the error is very reasonable, but it is directly handled by the Sharia Muamalat DPLK Pension Fund with confirmed directly to the participants concerned.

Operational risk is the last, $2 \mathrm{f}$. empty employees on important posts in organizational structures that cause employees working in multiple. Based on informant first (head of investment) the likelihood of the risk happening chances are almost certainly (5), and the impact caused when the risks occur is not significant (1). That is because the risk has been running for quite a while but not memiki impact so that the company can still run well.

The following is the operational risk matrix of the DPLK Pension Fund Sharia Muamalat:

\subsubsection{Risk of asset and liability}

Risk asset and liability is 3a. the results of the investment does not match the benchmark. Based on informant first (head of investment) level opportunity for those risks are likely to occur (4), while the level of impact when the risk is moderate (3). That is because in the capital markets is not all instruments can run the same as the benchmark, sometimes above the benchmark, and sometimes there are below the benchmark, in this case 
TABLE 5: Risk assessment Operational Risk (Source: data process by writer).

\begin{tabular}{|l|l|c|c|c|c|}
\hline Code & $\begin{array}{l}\text { Description of risk } \\
\text { 2a }\end{array}$ & $\begin{array}{l}\text { Opportunities } \\
\text { The connection between } \\
\text { the DPLK Pension Fund } \\
\text { Sharia Muamalat system } \\
\text { and the founder is Bank } \\
\text { Muamalat }\end{array}$ & 4 & Score & Level \\
\hline $2 \mathrm{~b}$ & $\begin{array}{l}\text { The system is turn over } \\
\text { Tc }\end{array}$ & 2 & 4 & 8 & $\mathrm{M}$ \\
\hline $\mathrm{2d}$ & $\begin{array}{l}\text { System failure } \\
\text { Error when inputting data }\end{array}$ & 4 & 1 & 3 & $\mathrm{R}$ \\
\hline $\mathrm{2e}$ & $\begin{array}{l}\text { Delay in sending files by } \\
\text { the branch office to the } \\
\text { head office }\end{array}$ & 4 & 2 & 8 & $\mathrm{M}$ \\
\hline $\mathrm{2f}$ & $\begin{array}{l}\text { Empty employees at } \\
\text { important positions in the } \\
\text { organizational structure }\end{array}$ & 5 & 1 & 5 & $\mathrm{M}$ \\
\hline
\end{tabular}

TABLE 6: Matrix Risk assessment operational risk (Source: data process by writer).
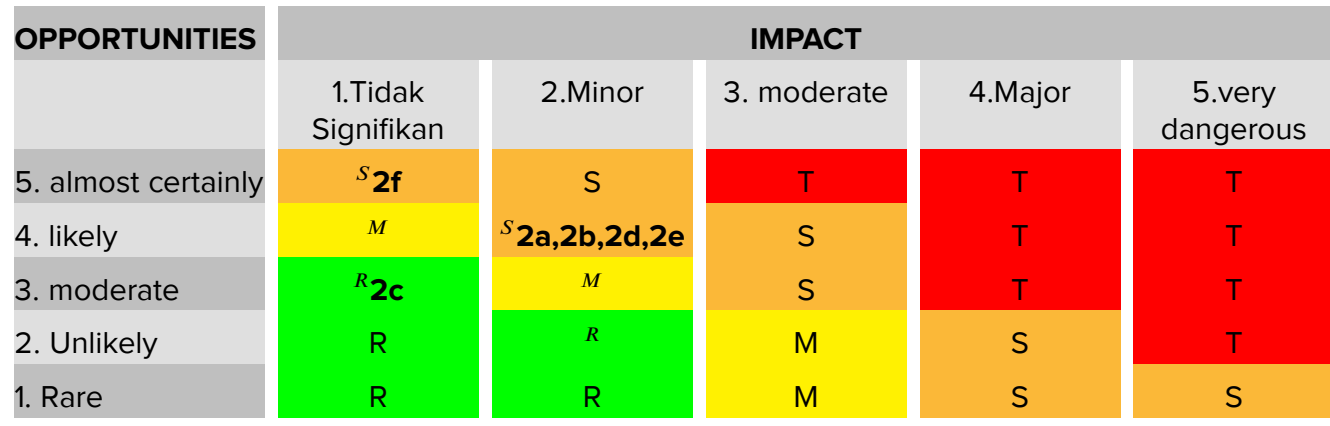

open and accountable Sharia DPLK Pension Fund if there were complaints from the participants, and will provide the best solution to the participants concerned.

The next risk is $3 \mathrm{~b}$. package selection error. Based on Informant first (head of investment), the chance of the occurrence of the electoral package have error may occur (4), while the impact has a level 4 because of an error in the package selection may result in a mismatch of results investment.

The next risk is $3 \mathrm{c}$. the risk of fluctuating or UPS and downs of stock market value. Based on the second informant (relation marketing), the chance of the occurrence of the risk of fluctuating are at level 4 and the impacts are on level 2 . This occurs because the DPLK Pension Fund Offer Sharia just became the Manager of the institution, in charge to manage the Fund participants, determine best period, and provide socialization to participants, the risk is real is at the customer.

The next risk is $3 \mathrm{~d}$. liquidity risk-related policies of the corporate participants about early retirement. Based on the fourth informant (Acting Superintendent) the chance of 
occurrence is at level 3 or under, and the impact that will be inflicted on a minor level (2). The following table of risk assessment and asset liquidity:

TABLE 7: Risk assessment Asset and Liability Risk (Source: data process by writer).

\begin{tabular}{l|l} 
code & Description of risk \\
3a & $\begin{array}{l}\text { Investment results that are } \\
\text { not in accordance with the } \\
\text { benchmark }\end{array}$ \\
3b & Error in package selection \\
3c & Risk of fluctuations \\
3d & Liquidity risk
\end{tabular}

\begin{tabular}{|c|}
\hline Opportunities \\
\hline 4 \\
\hline 4 \\
\hline 4 \\
\hline 3 \\
\hline
\end{tabular}

\begin{tabular}{|l|} 
Impact \\
3 \\
\\
\hline 4 \\
\hline 2 \\
\hline 2 \\
\hline
\end{tabular}

\begin{tabular}{|c|}
\hline Score \\
\hline 12 \\
\hline 16 \\
\hline 8 \\
\hline 6 \\
\hline
\end{tabular}

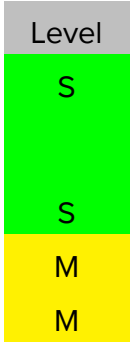

TABLE 8: Matrix Risk assessment Aset and Liabilitas Risk (Source: data process by writer).

\begin{tabular}{|c|c|c|c|c|c|}
\hline \multirow[t]{2}{*}{ OPPORTUNITIES } & \multicolumn{5}{|c|}{ IMPACT } \\
\hline & 1.Insignificant & 2.Minor & 3. moderate & 4.Major & $\begin{array}{c}5 . \text { very } \\
\text { dangerous }\end{array}$ \\
\hline 5. almost certainly & $S$ & $\mathrm{~S}$ & $\mathrm{~T}$ & $\mathrm{~T}$ & $\mathrm{~T}$ \\
\hline 4. likely & $M$ & ${ }^{s} \mathbf{3 c}$ & ${ }^{s} \mathbf{3 a}$ & T3b & $\mathrm{T}$ \\
\hline 3. moderate & $\mathrm{R}$ & ${ }^{M} \mathbf{3 d}$ & $\mathrm{S}$ & $\mathrm{T}$ & $\mathrm{T}$ \\
\hline 2. Unlikely & $\mathrm{R}$ & $R$ & M & $\mathrm{S}$ & $\mathrm{T}$ \\
\hline 1. Rare & $\mathrm{R}$ & $\mathrm{R}$ & M & $\mathrm{S}$ & $\mathrm{S}$ \\
\hline
\end{tabular}

\subsubsection{Risk reputation}

Reputational risk is the first 4a. participants will be exposed to negative issues. Based on informant first (head of investment), level opportunities for those risks that is likely to occur or be in level 4 , then the impact will be incurred when the risks occur are minor (2).

Reputational risk is $4 \mathrm{~b}$. due to the lack of participants reporting rendering to the media, and law enforcement authorities. Based on informant first (head of investment), the level of risk the chance is unlikely (2), and its impact adalahmayor (4). The following table of reputation risk assessment:

TABLE 9: Risk assessment Reputation risk (Source: data process by writer).

\begin{tabular}{l|l} 
Code & Description of risk \\
$4 a$ & $\begin{array}{l}\text { Participants will be } \\
\text { exposed to negative issues }\end{array}$ \\
$4 b$ & $\begin{array}{l}\text { Reporting participants to } \\
\text { social media and mass } \\
\text { media }\end{array}$
\end{tabular}

\begin{tabular}{|c|}
\hline Opportunities \\
4 \\
\hline 2 \\
\hline
\end{tabular}

\begin{tabular}{c} 
Impact \\
2 \\
4 \\
\hline
\end{tabular}

\begin{tabular}{c} 
Score \\
8 \\
8 \\
\hline
\end{tabular}

Level
M
M


TABLE 10: Matrix Risk assessment Reputation Risk (Source: data process by writer).

\begin{tabular}{l|c|c|c|c|c|}
\hline OPPORTUNITIES & \multicolumn{3}{|c}{ IMPACT } \\
& $\begin{array}{l}\text { 1.Tidak } \\
\text { Signifikan }\end{array}$ & 2.Minor & 3. moderate & 4.Major & $\begin{array}{c}\text { 5. very } \\
\text { dangerous }\end{array}$ \\
\hline 5. almost certainly & $S$ & $\mathrm{~S}$ & $\mathrm{~T}$ & $\mathrm{~T}$ & $\mathrm{~T}$ \\
\hline 4. likely & $M$ & $S_{\mathbf{4 a}}$ & $S$ & $\mathrm{~T}$ & $\mathrm{~T}$ \\
\hline 3. moderate & $\mathrm{R}$ & $M$ & $\mathrm{~S}$ & $\mathrm{~T}$ & $\mathrm{~T}$ \\
\hline 2. Unlikely & $\mathrm{R}$ & $R$ & $\mathrm{M}$ & $S \mathbf{4 b}$ & $\mathrm{T}$ \\
1. Rare & $\mathrm{R}$ & $\mathrm{R}$ & $\mathrm{M}$ & $\mathrm{S}$ & $\mathrm{S}$ \\
\hline
\end{tabular}

\subsubsection{Risk participants}

The risk of participants the first is 5 a. the risk of fluctuating. Based on informant fifth (customer) that the risk of stock market ups and downs may occur, and the impact that will be brought about if the risk is medium. That is because the stock market decline would cause harm to participants, so that participants should fully understand the types of investment packages in order not going wrong.

The second risk is 5b. package selection error. Based on informant sixth, the risk of error in choosing a package may occur, and the impact if the risk is medium. The following table risk assessment participants:

TABLE 11: Risk assessment Risk Participants (Source: data process by writer).

\begin{tabular}{l|l} 
Code & Description of risk \\
$5 a$ & $\begin{array}{l}\text { Naik turunnya nilai pasar } \\
\text { modal }\end{array}$ \\
45 & Kesalahan pemilihan paket
\end{tabular}

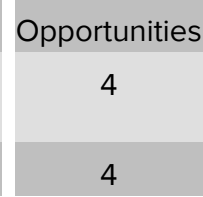

Impact
3
3

Score
12
12

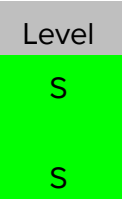

TABLE 12: Matrix Risk assessment Risk Participants (Source: data process by writer).
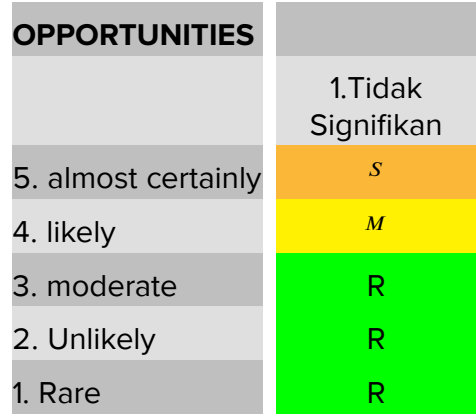

2.Minor
S
$S$
$M$
$R$
R

\section{IMPACT}

\begin{tabular}{c} 
3. moderate \\
\hline T \\
\hline $5 \mathbf{5 a}, \mathbf{5 b}$ \\
$\mathrm{S}$ \\
$\mathrm{M}$ \\
$\mathrm{M}$
\end{tabular}
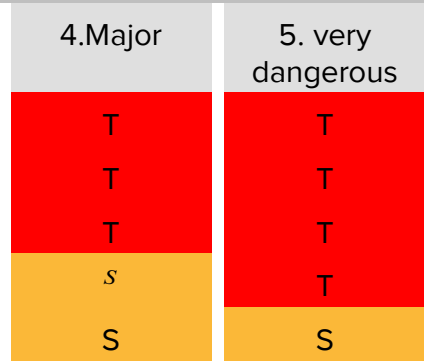

Based on an overall risk assessment of the six informants has been done then unknown level of risk from all risks identified that is low by as much as 4 types of risk description IE: 1b. Sharia Muamalat DPLK Pension Fund market share is still small, 1 c. Sharia Muamalat DPLK Pension Fund competition with others DPLK Pension Fund, 2 c. 
the failure of the system, $2 \mathrm{f}$. employees at the empty outposts important organizational structure.

Moderate levels by as much as 9 type descriptions that consist of 1a. yet familiar Sharia Muamalat DPLK Pension Fund by society, 2a. yet Sharia Muamalat DPLK Pension Fund D system connected with founders namely Bank Muamalat, 2b. turn over, $2 \mathrm{~d}$ systems. data input errors, 2 e. file delivery delays by the branch to head office, $3 \mathrm{c}$. the risk of fluctuating, 3d. liquidity risk, 4a terpengaruhnya of Bank Muamalat Sharia Muamalat DPLK Pension Fund as the founder, and $4 \mathrm{~b}$. reporting participants due to the mismatch of the investment package on social media, and the mass media.

A significant level of risk among other descriptions, 3a. investment results not in accordance with the benchmarks, 3b. participants select investment package error $5 \mathrm{a}$. the risk of fluctuating (participants), and 5b. errors in the selection of the investment package (participants). Following the risk assessment matrix table in the Sharia Muamalat DPLK Pension Fund.

TABLE 13: Matrix Risk assessment DPLK PENSION FUND Sharia Muamalat(Source: olah data peneliti).

\begin{tabular}{|c|c|c|c|c|c|}
\hline \multirow[t]{2}{*}{ OPPORTUNITIES } & \multicolumn{5}{|c|}{ IMPACT } \\
\hline & 1.Insignificant & 2.Minor & 3. moderate & 4.Major & $\begin{array}{c}\text { 5. very } \\
\text { dangerous }\end{array}$ \\
\hline 5. almost certainly & ${ }^{s} \mathbf{2 f}$ & $\mathrm{S}$ & $\mathrm{T}$ & T & $\mathrm{T}$ \\
\hline 4. likely & ${ }^{M}$ 1c & $\begin{array}{c}{ }^{S} 1 \mathrm{a}, \mathbf{2 a}, \mathbf{2 d}, \\
2 \mathrm{e}, 3 \mathrm{c}, \mathbf{4 a},\end{array}$ & ${ }^{s} \mathbf{3 a}, \mathbf{5 a}, \mathbf{5 b}$ & ${ }^{T} \mathbf{3 b}$ & $\mathrm{T}$ \\
\hline 3. moderate & $\mathrm{R} 2 \mathrm{c}$ & ${ }^{M} \mathbf{3 d}$ & $\mathrm{S}$ & $\mathrm{T}$ & $\mathrm{T}$ \\
\hline 2. Unlikely & $\mathrm{R}$ & ${ }^{R} \mathbf{1 b}$ & M & ${ }^{s} \mathbf{2 b , \mathbf { 4 b }}$ & $\mathrm{T}$ \\
\hline 1. Rare & $\mathrm{R}$ & $\mathrm{R}$ & $M$ & $\mathrm{~S}$ & $\mathrm{~S}$ \\
\hline
\end{tabular}

\section{Risk Treatment}

Following the handling of risks undertaken Sharia Muamalat DPLK Pension Fund against risks that have been identified.

\subsubsection{Stategy risk}

Based on research, the handler at risk of 1a. yet familiar Sharia Muamalat DPLK Pension Fund by the community by requesting a the approval of the Board to expand the network throughout Indonesia, because in Sharia Muamalat DPLK Pension Fund operation of branch offices of Muamalat is helpful to the development of Sharia Muamalat DPLK Pension Fund Indonesia. 
Furthermore, the handling of risk to $1 \mathrm{~b}$. the low market share of Sharia Muamalat DPLK Pension Fund by asked the Sharia Board approval to provide key performance indicators to support the retirement fund for Sharia products sales so that the market share of Sharia Muamalat DPLK Pension Fund.

The last Chief risk handling i.e. 1 c. Sharia Muamalat DPLK Pension Fund competition with others DPLK Pension Fund namely with handling the risk of Sharia Muamalat DPLK Pension Fund strategies, particularly for the planned severance Muamalat Sharia Muamalat DPLK Pension Fund, trying to market the product in a manner presented the excellence, product, management processes without each others Sharia Muamalat DPLK Pension Fund between, in addition in Sharia Muamalat DPLK Pension Fund product marketing assisted by Branch Office, and provides maximum service. so that in the selection of participants, diperknankan DPLK PENSION FUND to choose in accordance with their conscience, and without any element of coercion

\subsubsection{Operational risk}

Based on research, the handler at risk of 2a. yet Sharia Muamalat DPLK Pension Fund system terkoneksinya with Bank Muamalat is to connect only on the important outposts in the structure of the Organization, as well as in terms of dues, investments, because when the overall risk will be connected getting bigger.

Handling risk next is $2 \mathrm{~b}$. systems that turn over that is by the way by providing innovation and improve the existing system.

Handling risk next is $2 \mathrm{c}$. the failure of the system, namely by way of asking for help fixing IT's founder, and improve internal systems, in addition to Sharia Muamalat DPLK Pension Fund also requested assistance to the branch to immediately confirm when the login failure occurred.

Handling risk next is, $2 d$. error when penginputan data, i.e. by way of asking for help to the branch to be penghimbauan against participants in order for the participants to write down data correspond to the ID card and the account is active. Additionally Sharia Muamalat DPLK Pension Fund puts checker maker approval and must do reporting of consumer complaints and settlement services for three months to minimize the risk to OJK (Indonesia Financial Services Authority) will arise.

The next risk is a risk handling $2 \mathrm{e}$. file delivery delays by the branch to head office, i.e. by way of doing appeal to branch to do the checking back and to immediately sent in accordance with SOP apply, and put forward checher, maker, approval. 
The handling of operational risk is $2 \mathrm{f}$. employees at the empty outposts important organizational structure, i.e. by way of conveying and begged approval for the addition of employees because in Sharia Muamalat DPLK Pension Fund organizational structure, employees on important posts filled by Bank employees Muamalat.

\subsubsection{Risk of asset and liability}

Handling risk asset and liability is 3a. the results of the investment does not match the benchmark i.e. by way of educating, in addition in Sharia Muamalat DPLK Pension Fund investment calculations gonna recruit of competent human resources.

The handling of risk assets and liabilities to the next is $3 \mathrm{~b}$. package selection error risks by providing packages that fit the risk profile of the participants, and the investment team acts to determine the position of the best period in the capital markets.

Handling risk next is $3 \mathrm{c}$. the risk of fluctuating by way of election of the capital market, must comply with the investment grade.

Handling risk next is $1 \mathrm{~d}$. corporate participants policy will retire early, i.e. in a manner providing or mencover Fund participants who entered the retirement age in the next 5 years.

\subsubsection{Reputational risk}

Based on research, handling of reputational risk at 4a. participants' influence on negative issues that is by way of explaining that, there is a difference between the kind of Sharia Muamalat DPLK PENSION FUND business with Bank Muamalat, Sharia Muamalat DPLK Pension Fund additionally focus on maximum service.

Handling of reputational risk next is $4 \mathrm{~b}$. reporting of participant to the media, and law enforcement authorities, namely by means of memaintenance participants, and checked against the results of the investment.

\subsubsection{The risk of participants}

Handling risk participants the first is 5 a. fluctuates with the way the participant should be familiar with the capital markets. That is because the pemahamam of the capital market will minimize errors when the selection of investments. 
Handling risk next is 5b. error selecting the investment package, namely by means of the selection of the investment package should be adapted to the profile of the participants, and with followed by a knowledge of the investment package.

\section{Cover}

\subsection{Conclusion}

Based on research conducted towards risk management on the management of the Sharia Muamalat DPLK Pension Fund, then the conclusion can be drawn from this study, among others, on the management of Sharia Muamalat DPLK Pension Fund financial institutions in Sharia Muamalat DPLK Pension Fund there are 5 This type of risk is identified that is composed of risk strategy, operational risk, the risk of an asset and a liability, reputational risk, and the risk of participants. From 5 kinds of risks there are 17 types of descriptions of risk. The results obtained from the assessment of the risk of generating significant levels of as much as 4 types of descriptions of risk, moderate levels of as much as 9 types of descriptions of risk, and low levels of as much as 4 types of descriptions of risk. Sharia Muamalat DPLK Pension Fund assess overall risk is based on the belief that was born from all possibility of risks that have been experienced on previous experience and the berdarkan on general knowledge. Sharia Muamalat DPLK Pension Fund has a main concept of handling risks by selecting the right people and experts in the field, as well as involving the founder and branch offices in handling.

\subsection{Suggestions}

Based on the research results and discussion above, then submitted some suggestions as follows:

1. For the Sharia Muamalat DPLK Pension Fund is expected to note in particular the risk of a significant level, moderate with immediate do penangana risks

2. For the Regulator

For regulators is expected to make a special risk management standards for Sharia Muamalat DPLK Pension Fund

\section{For Customer}


the customer is expected to open an investment package of options knowledge will be provided, and to undertake the selection of a package of investments in accordance with the client's risk profile.

4. Clients for the Next Researcher

Further research is expected to be examined further on matters relating to the management of the risk of DPLK Pension Funds.

\subsection{Limitations of research}

The limitations of the researcher at the time of the study was the lack of literature about risk management management of the Sharia Muamalat DPLK Pension Fund.

\section{References}

[1] Ahmed, T. K. (2008). Manajemen Risiko Lembaga Keuangan Sharia. Jakarta : Sinar Grafika Offset.

[2] Australian/New Zealand Standard 4360:1999. RiskManagement.Sydney:Standard Australia

[3] _ ISO 31000:2009. Risk Management Principle andGuidelines.Sydney:Standard Australia

[4] Christina. (2012). Asesmen Risiko Berbasis ISO31000:2009.

[5] Djazuli, A. (2006). Kaidah-Kaidah Fiqih. Jakarta: Kencana Persada Media Group.

[6] Djojosoedarso, S. (1999). Prinsip-Prinsip Manajemen Risiko dan Asuransi. Jakarta: Salemba Empat.

[7] Fatwa Dewan Sharia Nasional Nomor:88/DSN-MUI/XI/2013 Tentang Pedoman Umum Penyelenggaraan Progam Dana Pensiun Sharia.

[8] FIFI, R. (2015). Analisis Penerapan Manajemen Risiko Terhadap Ketidakpastian (uncertainty) yang Menghambat Pencapaian Tujuan Perusahaan \{Studi Kasus pada PT. TASPEN (PERSERO)\}.

[9] Hery. (2015). Manajemen Risiko Bisnis: Enterprise Risk Management. Jakarta: PT Grasindo.

[10] https://sikapiuangmu.ojk.go.id/FrontEnd/CMS/Article/344. diakses pada 10 Mei 2018 pukul 16.15

[11] Huda, N. d. (2010). Lembaga Keuanagan Islam. Jakarta: Kencana.

[12] Irmayanto, Juli, dkk. (2004) Bank dan Lembaga Keuangaan. Jakarta 
[13] J Andersen M Garvey, d. O. (2014). Managing Risk and Opportuniy. United Kingdom: CPI Group.

[14] Karim A, A. (2014). Bank Islam:Analisis Fiqih dan Keuangan. Jakarta: PT. Raja Grafindo Persada.

[15] Moelong, L. J. (2009). Metode Penelitian Kualitatif. Bandung: PT Remaja Rosdakarya.

[16] Mildaeni, I. N. (2014). Konsep Risiko dalam Perspektif Islam: Studi Hermeneutik Terhadap Karya Ibnu Taimiyah dan Al-Ghazali tentang khauf wa raja'

[17] Oscar Akotey, J. a. (2013). Risk management in the Ghanaian insurance industry. Qualitative Research in Financial Markets , 5(1), pp.26-42.

[18] P.Siagian, S. (1994). Teori dan Praktek Kepemimpinan. Jakarta: Penerbit Rhineka Cipta.h.192 Terry G.R. Principle Of Management.(New York: Richard.D. Irwin, Inc.1977).

[19] Peraturan Otoritas Jasa Keuangan Nomor 33/POJK.05/2016 tentang Penyelenggaraan Program Pensiun Berdasarkan Prinsip Sharia.

[20] Kementrian Agama RI (2014). Mushaf At-Tammam Al-Qur'an dan Terjemahanya. Solo: PT. Tiga Serangkai Pustaka Mandir.

[21] Risk Management in Insurance. (1999). Journal of Financial Regulation and Compliance , 7(1), pp.13-16.

[22] Siamat, Dahlan. (2004) Manajemen Lembaga Keuangan ed 4, Jakarta : Lembaga Penerbit Fakultas Ekonomi Universitas Indonesia.

[23] Soemitra, A. (2009). Bank dan Lembaga Keuangan Sharia. Jakarta: Kencana.

[24] Sugiyono. (2012). Metode Penelitian Pendidikan. Bandung: Alfabeta.

[25] Surat Edaran Otoritas Jasa Keuangan Nomor 10 /SEOJK.05/2016 Tentang Pedoman Penerapan Manajemen Risiko dan Laporan hasil.

[26] Undang-Undang No 11 tahun 1992 Tentang Dana Pensiun.

[27] Wahyudi. (2013). Manajemen Risiko Bank Islam. Jakarta: Salemba Empat.

[28] Wiruth, K. G. (1976). Practical Risk Analysis for Safety Management.

[29] www.bankmuamalat.co.id. diakses pada 14 Mei 2018 pukul 22.10

[30] www.ojk.go.id. diakses pada 13 Mei 2018 pukul 19.35

[31] Yin, R. K. (2014). Case Study Research Design and Methods 5 Edition. Los Angeles: SAGE.

[32] _ (2016). Qualitative Research From Start to Finish, Second Edition. New York: The Guilford Presse .

[33] _ (2015). Studi Kasus Design \& Metode. Jakarta: Raja Grafindo Persada.

[34] _ (2009). Studi Kasus: Desain \& Metode. Jakarta: Rajawali Pers. 
[35] Yusuf, M. (2014). Metode Penelitian: Kuantitatif, Kualitatif, dan Penelitian Gabungan. Jakarta: Prenadamedia Grup.

[36] Zulaini, W. (2005). Segi Hukum Dana Pensiun. Jakarta: PT. Raja Grafindo. 